\title{
Anoctamin 9/TMEM16J is a Cation Channel Activated by cAMP/PKA Signal
}

Hyungsup Kim ${ }^{1,2}$, Hyesu Kim ${ }^{1,2}$, Jesun Lee ${ }^{1}$, Byeongjun Lee ${ }^{2}$, Heeryang Kim ${ }^{1}$,
Jooyoung Jung ${ }^{2}$, Mi-Ock Lee ${ }^{1 *}$ and Uhtaek Oh ${ }^{1,2,{ }^{*}}$

${ }^{1}$ College of Pharmacy, Seoul National University, Seoul 08826, Korea.

${ }^{2}$ Brain Science Institute, Korea Institute of Science and Technology (KIST), Seoul 02792, Korea. 


\begin{abstract}
Anoctamins are membrane proteins that consist of 10 homologs. ANO1 and ANO2 are anion channels activated by intracellular calcium that meditate numerous physiological functions. ANO6 is a scramblase that redistributes phospholipids across the cell membrane. However, the others are not well characterized. We found ANO9/TMEM16J is a cation channel activated by a cAMP-dependent PKA. Intracellular cAMP activated robust currents in whole-cells expressing ANO9 and inhibited by PKA blockers. A cholera toxin and purified PKA also activated ANO9. The cAMP-induced ANO9 currents were permeable to cations. The mutation of a possible phosphorylation site at Ser245 elicited a block of the cAMP-dependent activation. High levels of Ano9 transcripts were found in intestines. Human intestinal SW480 cells showed cAMP-dependent currents. We conclude that ANO9 is a cation channel activated by the cAMP/PKA pathway and could play a role in intestine function.
\end{abstract}




\section{INTRODUCTION}

The Anoctamin/TMEM16 family consists of transmembrane proteins in 10 isoforms, ranging from ANO1/TMEM16A to ANO10/TMEM16K. Anoctamins are expressed in numerous major tissues and are thought to mediate various physiological functions. The best known anoctamin gene is Ano1, which is a $\mathrm{Cl}^{-}$channel activated by $\mathrm{Ca}^{2+}$ (Caputo et al, 2008; Schroeder et al, 2008; Yang et al, 2008). ANO1 is known to mediate transepithelial fluid movements such as salivation in the salivary glands, mucin secretion in the airway and $\mathrm{Cl}^{-}$and fluid secretion in the intestine (Huang et al, 2012a; Jang \& Oh, 2014; Namkung et al, 2011; Ousingsawat et al, 2009; Romanenko et al, 2010). ANO1 is also highly expressed in small-diameter dorsal-root ganglion neurons, implicating its role in nociception as a heat sensor (Cho et al, 2012). In addition, ANO1 plays an important role in controlling smooth muscle contraction (Bulley et al, 2012) and pacemaking activity in the intestine (Cobine et al, 2017; Hwang et al, 2009). More importantly, ANO1 has been implicated in tumorigenesis (Britschgi et al, 2013; Duvvuri et al, 2012; Jia et al, 2015) and benign prostate hyperplasia (Cha et al, 2015).

ANO2 is a $\mathrm{Cl}^{-}$channel activated by $\mathrm{Ca}^{2+}$ and is thus also considered a $\mathrm{Ca}^{2+}-$ activated $\mathrm{Cl}^{-}$channel (Huang et al, 2012a; Pifferi et al, 2009). ANO2 has physiological functions distinct from ANO1; it controls sensory transduction and synaptic plasticity in the central nervous system (Huang et al, 2012b; Zhang et al, 2015) as well as olfactory transduction and phototransduction (Billig et al, 2011; Dauner et al, 2013; Keckeis et al, 2017; Pietra \& Dibattista, 2016; Stephan et al, 2009). In addition, ANO2 is also involved in smooth muscle contraction (Bernstein et al, 2014; Forrest et al, 2010). 
Unlike ANO1 and ANO2, ANO6/TMEM16F has dual functions. ANO6 is a small conductance calcium activated cation channel (SCAM) that is permeable to divalent ions (Yang et al, 2012). Strikingly, ANO6 is known to be a scramblase that disrupts polarized phospholipids in the plasma membrane. The polarized phospholipids attract immunological signals necessary for activation of T lymphocytes (Hu et al, 2016; Xu et al, 2008; Zhang et al, 2011). Mutations in Ano6 cause a rare bleeding disease, Scott syndrome (Castoldi et al, 2011; Suzuki et al, 2010). Thus, ANO6 is both a channel and an enzyme. Some scramblase activity has also been observed in ANO4, ANO8 and ANO9 .

ANO5 is involved in skeletomuscular function; its mutations cause gnathodiaphyseal dysplasia, an autosomal dominant inherited bone disorder (Tran et al, 2014). However, its biophysical properties and mechanism of activation are unknown.

Although the functional roles of some genes in the Anoctamin family are well studied, the role of ANO9/TMEM16J remains poorly understood (Picollo et al, 2015). ANO9 is found in the human nasal and colonic epithelium and expressed in the respiratory, digestive, skeletal and integumentary systems during development (Rock \& Harfe, 2008). ANO9 is also implicated in the metastasis of colorectal cancer (Li et al, 2015). Despite its expression pattern and a possible role in colorectal tumorigenesis, the function and activation mechanism of ANO9 is not known. The present study aimed to determine if ANO9 is a channel and, if so, how it is activated. Surprisingly, we found that ANO9 is a cation channel activated by the cAMP/PKA pathway. 


\section{RESULTS}

\section{cAMP activates ANO9}

To determine if ANO9 is a channel, we expressed mouse ANO9 tagged on the C terminus with enhanced green fluorescence protein (eGFP) for visual identification in HEK 293T cells. The eGFP was largely localized in the plasma membrane (Fig. 1A). Upon whole-cell formation in the HEK 293T cells transfected with Ano9-eGFP (ANO9/HEK cells), robust inward currents $(65.9 \pm 6.99 \mathrm{pA} / \mathrm{pF}, \mathrm{n}=36)$ were observed with $E_{\text {hold }}=-60 \mathrm{mV}$ when the pipette solution contained $100 \mu \mathrm{M}$ cAMP. The bath and pipette solutions contained $140 \mathrm{mM} \mathrm{NaCl}$ and $140 \mathrm{mM} \mathrm{KCl}$, respectively. These currents were not observed in whole cells without cAMP in the pipette. In addition, the cAMP-evoked currents were completely blocked by the treatment of the cells with PKA blockers $(20 \mu \mathrm{M} \mathrm{H}-7$ or $20 \mu \mathrm{M} \mathrm{H}-89$; Fig. 1B \& 1C). cGMP in the pipettes $(100 \mu \mathrm{M})$ failed to evoke currents in ANO9/HEK cells (Fig. 1D). The cAMP-evoked currents in the ANO9/HEK cells began to develop $5 \mathrm{~s}$ to a few minutes after the formation of whole-cells. This time lag suggests a possible indirect signaling pathway for the activation by cAMP.

Cholera toxin is an oligomeric protein complex secreted by the bacterium Vibrio cholerae that leads to the direct activation of adenylyl cyclase, resulting in the overproduction of cAMP (Gabriel et al, 1994). If ANO9 is activated by cAMP and its downstream signal, then the application of cholera toxin should activate ANO9. Indeed, the application of cholera toxin to the bath solution evoked robust currents with variable time lags in ANO9/HEK cells. However, the cholera toxin-induced currents were not observed in the mock-transfected HEK 293T cells (Fig. 1E \& 1F). 


\section{PKA activates ANO9}

We then tested whether cAMP alone or with its downstream signal, PKA, activated ANO9. To do this, membrane patches were isolated from ANO9/HEK cells with an inside-out patch configuration. Recordings were made in a pipette solution containing $140 \mathrm{mM} \mathrm{NaCl}$ and $2 \mathrm{mM} \mathrm{CaCl}_{2}$ and a bath solution containing $140 \mathrm{mM} \mathrm{KCl}$ at $\mathrm{E}_{\text {hold }}=$ $-60 \mathrm{mV}$. When solutions containing $1 \mathrm{mM}$ cAMP, $2 \mathrm{mM}$ ATP or cAMP+ATP were applied to the inside-out patches, no appreciable currents were observed (Fig. 2A). However, when purified PKA (10 $\mu \mathrm{g} /$ reaction, 0.7 units $/ \mu \mathrm{g})$ along with ATP and cAMP was applied to isolated membrane patches of ANO9/HEK cells, large macroscopic currents were observed with a prolonged time lag (Fig. 2A). These results now suggest that ANO9 is activated by PKA activity.

\section{ANO9 is a cation channel}

The cAMP-evoked currents in ANO9/HEK cells were cationic because they were not observed in the bath solution containing $140 \mathrm{mM} \mathrm{N}$-methyl D-glucamine (NMDG)$\mathrm{Cl}$ (Fig. 3A \& 3B). Ion selectivity was determined by a shift in reversal potential in whole cells in which extracellular $\mathrm{KCl}$ solution was changed to 70 and $210 \mathrm{mM}$. The pipette solution contained $140 \mathrm{mM} \mathrm{KCl}$. The current-voltage (I-V) relationship was obtained to measure the reversal potential. Voltage ramps from $-100 \mathrm{mV}$ to $+100 \mathrm{mV}$ in $100 \mathrm{~ms}$ durations were applied. When the bath $\mathrm{KCl}$ concentration, initially $140 \mathrm{mM}$, was changed to $210 \mathrm{mM}$ and $70 \mathrm{mM}$, the reversal potentials were changed to $+6.29 \pm 0.82$ $\mathrm{mV}$ and $-11.46 \pm 1.09 \mathrm{mV}(\mathrm{n}=8)$, respectively (Fig. 3C). The reversal potentials were plotted as a function of extracellular $\mathrm{KCl}$ concentration on a semi-logarithmic scale. $\mathrm{A}$ 
line was fitted to $+37.2 \mathrm{mV} /$ decade, which is relatively close to $+58 \mathrm{mV} /$ decade of the Nernst equation when the major carrier charge is a cation. The relative permeability ratio of $\mathrm{K}^{+}$and $\mathrm{Cl}^{-}\left(\mathrm{P}_{\mathrm{Cl}} / \mathrm{P}_{\mathrm{K}}\right)$ calculated by Goldman-Hodgkin-Katz equation (Hille, 2001) is $0.237 \pm 0.034$, suggesting a weak permeability to $\mathrm{Cl}^{-}$. Thus, these results clearly suggest that ANO9 exhibits a large preference for cations.

We then explored the selectivity among cations by estimating the permeability ratios after replacing the $140 \mathrm{mM} \mathrm{KCl}$ solution in the bath with a solution of $70 \mathrm{mM}$ $\mathrm{CaCl}_{2}$ and $\mathrm{CsCl}$ and $140 \mathrm{mM}$ of $\mathrm{NaCl}$ and $\mathrm{LiCl}$. The pipette solution contained $140 \mathrm{mM}$ $\mathrm{KCl}$. The reversal potentials were $-2.07 \pm 1.56,-7.83 \pm 1.25,-5.42 \pm 1.43$ and $-12.6 \pm$ $2.96 \mathrm{mV}$ when the bath $\mathrm{K}^{+}$solution was changed to $\mathrm{Ca}^{2+}, \mathrm{Cs}^{+}, \mathrm{Na}^{+}$, and $\mathrm{Li}^{+}$, respectively (Fig. 3D). The relative permeability ratios ( $\left.\mathrm{P}_{\mathrm{x}} / \mathrm{P}_{\mathrm{K}}\right)$ ranged from 0.54 to 1.87 (Fig. 3E), suggesting that ANO9 discriminated poorly among cations but was more permeable to $\mathrm{Ca}^{2+}$ than to monovalent cations.

Because both ANO1 and ANO2 are known to be voltage-activated (Cenedese et al, 2012; Xiao et al, 2011), we investigated if ANO9 was also activated by voltage alone. We increased the voltage in $20 \mathrm{mV}$ steps from $-120 \mathrm{mV}$ to $120 \mathrm{mV}$ and applied it to the whole cells of mock- and ANO9-transfected HEK cells. The I-V curves of ANO9transfected cells were outwardly rectifying (Fig. 3G). However, there was no difference between the amplitudes and shapes of the I-V curves of mock- and ANO9-transfected cells, suggesting that voltage alone does not activate ANO9.

\section{Possible PKA phosphorylation site}

Because ANO9 was activated by PKA, we identified its phosphorylation site. Five putative PKA phosphorylation consensus sites (R-R/K-X-S/T, R-X-X-S/T, and R-X-S/T) 
were predicted by a computer program, GPS 2.0 (Xue et al, 2008). These putative sites were the S85, S120, S245, S321 and T412 residues in ANO9. Using mutagenesis, each Ser or Thr residue of the predicted phosphorylation sites was replaced with alanine. Each mutant of ANO9 tagged with eGFP was expressed in HEK293T cells and tested for activation by cAMP. Each ANO9 mutant except T412A was well expressed in the plasma membrane of HEK293T cells (Supplementary Fig. 1). Robust cation currents were observed in HEK293T cells transfected with S85A, S120A and S321A mutants by $100 \mu \mathrm{M}$ cAMP in the pipette. However, cAMP failed to evoke cation currents in HEK293T cells transfected with S245A mutant of ANO9 (Fig. 4A \& 4B).

The activation of each ANO9 mutant by intracellular cAMP was also determined by calcium imaging experiments. The wild-type ANO9-expressing cells displayed irregular calcium signals after the treatment with $2 \mathrm{mM} \mathrm{N6,2'-O-dibutyryladenosine}$ 3',5'-cyclic monophosphate (db-cAMP), a cell-permeable form of cAMP. The db-cAMPinduced $\mathrm{Ca}^{2+}$ transients were blocked by the pretreatment with $\mathrm{H}-89$ (Fig. 4C). The dbcAMP-evoked calcium transients were not detected in the mock- or S245A mutanttransfected HEK293T cells (Fig. 4C \& 4D).

Oddly, the Ser245 residue is located in the extracellular loop of the predicted topology of ANO9 based on the modeling extracted from the crystal structure of nhTMEM16 (Brunner et al, 2014) (Fig. 4E). In this model, the $\mathrm{N}$ - and C-termini are present in the cytosolic side of the protein (Predicted model, Fig. 4E). If this is true, the Ser245 is hardly phosphorylated by PKA. However, the actual topology of ANO9 may differ from that predicted by the structure of nhTMEM16. If the Ser245 residue is present in the intracellular side, then the $\mathrm{N}$ - and $\mathrm{C}$-termini may be present in the 
extracellular side of the protein as shown in a revised model in Fig. 4E. To determine if the Ser245 residue is located on the intracellular side, we constructed fusion proteins in which the HA epitope tag was attached to the N-terminus or inserted next to the Ser245 of ANO9. These HA-tagged mutants of ANO9 were transfected to HEK cells. The HA antibody was applied to the extracellular side of the transfected cells and was detected by a fluorescent-tagged secondary antibody to anti-rabbit IgG. As shown in Fig. 4F, the HA tag was detected by the HA antibody applied extracellularly to nonpermeabilized as well as permeabilized HEK cells that were transfected with HAtagged ANO9 in the N-terminus, suggesting that the actual N-terminus of ANO9 is present in the extracellular side. In addition, the HA-tag was detected only in permeabilized cells expressing the ANO9 mutant where the HA tag was inserted next to the Ser245 residue whereas it was not detected by the antibody in nonpermeabilized cells (Fig. 4F). These results suggest that the Ser245 residue is located inside the cell.

\section{Calcium augments the cAMP-induced ANO9 currents}

Because ANO1 and ANO2 are known to be activated by intracellular $\mathrm{Ca}^{2+}$, we also tested for the activation of ANO9 by $\mathrm{Ca}^{2+}$. When $1 \mu \mathrm{M} \mathrm{Ca}^{2+}$ was applied to the pipette, no appreciable whole-cell currents were activated. When $10 \mu \mathrm{M} \mathrm{Ca}^{2+}$ was applied, small currents were observed (Fig. 5A \& 5B). When $20 \mu \mathrm{M}$ cAMP was applied together with $10 \mu \mathrm{M} \mathrm{Ca}^{2+}$, much larger currents than those activated by $10 \mu \mathrm{M} \mathrm{Ca}^{2+}$ alone were observed. These current responses to the co-application of $\mathrm{Ca}^{2+}$ and cAMP appeared to be dose dependent because larger currents were observed when 100 and $200 \mu \mathrm{M}$ 
cAMP were applied along with $10 \mu \mathrm{M} \mathrm{Ca}^{2+}$ (Fig. 5A \& 5B). Although the intracellular $\mathrm{Ca}^{2+}$ in a physiological concentration rarely activated $\mathrm{ANO}, \mathrm{Ca}^{2+}$ can augment the ANO9 response to cAMP.

\section{Intracellular sodium inhibits ANO9}

Unexpectedly, we also found that a high intracellular concentration of $\mathrm{Na}^{+}$inhibits the activity of ANO9. Intracellular cAMP vigorously activated ANO9 when $0 \mathrm{mM} \mathrm{Na}{ }^{+}$ was added to the pipette (intracellular) solution. However, when $50 \mathrm{mM} \mathrm{NaCl}$ was added to the pipette solution, the cAMP-evoked whole-cell currents were markedly reduced (Fig. 6A \& 6B). In contrast, when $50 \mathrm{mM} \mathrm{CsCl}$ was added to the pipette solution, the cAMP-evoked currents were comparable to those of the pipette solution containing $150 \mathrm{mM} \mathrm{KCl}$ (Fig. 6A \& 6B). These results suggest that high intracellular concentration of $\mathrm{Na}^{+}$inhibited the cAMP-dependent ANO9 activity.

\section{Ano9 is rich in intestines}

Tissue distribution of Ano9 was determined. Ano9 mRNAs were mainly observed in the digestive system. The small intestine, colon and stomach expressed large number of copies of Ano9 mRNA. A small amount of Ano9 mRNA was also detected in the tongue, kidney, eye, lung, and bladder (Fig. 7A).

Consistent with high expression in the colon, ANO9 is known to be expressed in colorectal cancer cells (SW480) ( $\mathrm{Li}$ et al, 2015). Indeed, the ANO9 specific immunofluorescence was present in the plasma membrane of SW480 cells when probed with ANO9 antibody (Fig. 7B). We therefore determined if cAMP activated the cation currents in these cells. Shown in Fig. 6C, the intracellular application of $100 \mu \mathrm{M}$ 
cAMP resulted in large inward currents in 15 out of 20 SW480 cells (Fig. 7C). The cAMP-evoked currents were blocked by co-challenge with $20 \mu \mathrm{M} \mathrm{H}-89$ in the pipette solution. In addition, a knock-down of Ano9 in the SW480 cells after transfection with siRNA of Ano9 markedly reduced the cAMP-evoked currents (Fig. 7C \& 7D). These results demonstrate that the native ANO9 in colorectal cells is activated by intracellular cAMP.

\section{DISCUSSION}

\section{Diverse functions of the anoctamin family}

The anoctamins have 10 homologs with diverse cellular and physiological functions. ANO1 was first discovered as a calcium-activated chloride channel (Caputo et al, 2008; Yang et al, 2008) and is known to be involved in many physiological functions such as fluid secretion, smooth muscle contraction, nociception, tumorigenesis and cell proliferation (Cho et al, 2012; Duvvuri et al, 2012; Huang et al, 2012a; Jang \& Oh, 2014; Katoh \& Katoh, 2003; Namkung et al, 2011; Ousingsawat et al, 2009; Romanenko et al, 2010). ANO2 is also known to be a calcium-activated chloride channel with olfaction and learning and memory functions (Billig et al, 2011; Huang et al, 2012b; Neureither et al, 2017; Pietra \& Dibattista, 2016; Stephan et al, 2009). ANO3 is known to increase modulation of the activity of the $\mathrm{Na}^{+}$-activated $\mathrm{K}^{+}$ channel in dorsal-root ganglion neurons, and it also modulates nociception (Huang et al, 2013). ANO5, expressed in muscles and bones, has been implicated in skeletomuscular functions because its mutations cause a skeletomuscular disease, 
gnathodiaphyseal dysplasia (Tran et al, 2014). Despite their physiological implications, however, the activation mechanisms and other cellular functions of ANO3 and ANO5 are not well characterized. ANO6 was initially characterized as a scramblase that disrupted polarized phospholipids in the plasma membrane (Castoldi et al, 2011; Suzuki et al, 2010). Later, ANO6 was found to be a cation channel activated by $\mathrm{Ca}^{2+}$ (Yang et al, 2012). Despite the diverse functions of anoctamins, the activation mechanisms of those other than ANO1, ANO2 and ANO6 are not well understood.

Unlike ANO1 and ANO2, ANO9 was permeated mainly by cations. The ANO9 currents were not blocked by the ANO1 blockers such as MONNA, NPPB, or tannic acid (Fig. 1B \& 1C). More importantly, ANO9 was activated by the cAMP/PKA pathway but not by $\mathrm{Ca}^{2+}$ or voltage. However, the activation by PKA was augmented by intracellular $\mathrm{Ca}^{2+}$. Although ANO9 is known to be expressed in the intestines, its physiological function is largely unknown.

\section{Role in colorectal cancer cells}

ANO9 has been implicated in intestinal functions; notably, its transcription levels were much higher in intestines compared to other tissues (Fig. 7A; (Schreiber et al, 2015; Schreiber et al, 2010)). It is expressed in the colorectal cancer cell line, SW480 cells. We observed cAMP-activated and H-89-reversible currents in the SW480 cells (Fig. 7), and ANO9 has been linked to colorectal cancer (Li et al, 2015). The activity of ANO9 was negatively associated with tumorigenesis in the colon. The expression of ANO9 was higher in non-tumor tissue than in tumorous tissues. ANO9 expression was lower in the recurrent colorectal cancer cells than in non-recurrent colorectal cancer cells. ANO9 overexpression is known to reduce the invasion of cancer cells ( $\mathrm{Li}$ et al, 
2015). Lower levels of ANO9 expression have been associated with poorer prognoses in patients with higher expression levels (Li et al, 2015). Thus, ANO9 appears to play a tumor suppressor role in the intestines, but its precise pathophysiological role needs to be determined.

\section{Calcium dependence}

$\mathrm{Ca}^{2+}$ is indispensable for anoctamin functions, and it activates ANO1 and ANO2 (Caputo et al, 2008; Schroeder et al, 2008; Stephan et al, 2009; Yang et al, 2008). $\mathrm{Ca}^{2+}$ is also required for the scramblase activity of ANO6 and fungal TMEM16 (Malvezzi et al, 2013; Suzuki et al, 2010; Yang et al, 2012). However, $\mathrm{Ca}^{2+}$ was not found to be essential for the activation of ANO9 because physiological concentrations of $\mathrm{Ca}^{2+}$ rarely gated ANO9. In addition, cAMP activated ANO9 in $\mathrm{Ca}^{2+}$-free conditions, but $\mathrm{Ca}^{2+}$ augmented the cAMP-induced ANO9 currents. Thus, the role of $\mathrm{Ca}^{2+}$ in activating ANO9 cannot be totally ignored because $\mathrm{Ca}^{2+}$ affected the ANO9 activity. Recently, the X-ray crystal structure of nhTMEM16 was determined (Brunner et al, 2014). The Glu residues of ANO1 essential for its activation by $\mathrm{Ca}^{2+}$ were located in the subunit cavity of ANO1 in the hydrophobic core of the membrane. The subunit cavity was lined by three glutamates, two aspartates and an asparagine residue in the $\alpha$-helices 6,7 , and 8 of nhTMEM16 and ANO1. These helices are known to be crucial for the channel activation of ANO1 and its scramblase activity (Brunner et al, 2014). ANO9 has a similar amino-acid sequence in this region (Supplementary Fig. 2): ANO9 has three glutamates, one aspartate and one serine residue in the $\alpha$-helices 7 and 8 . This structural constraint of ANO9 compared to ANO1 predicts the synergistic but not essential role of $\mathrm{Ca}^{2+}$ in activating ANO9. Voltage has been found to be another 
endogenous activator of ANO1 and ANO2, but, analogous to the role of $\mathrm{Ca}^{2+}, \mathrm{ANO} 9$ was not activated by voltage alone (Fig. 3F \& 3G). We found that ANO9 added more to the diversity of the functions of the anoctamin family.

\section{PKA activation}

Many of the functions of the cystic fibrosis transmembrane conductance regulator (CFTR), such as the transepithelial $\mathrm{Cl}^{-}$transport in various epithelia, overlap with those of ANO1 mainly because they are both anion channels. Because of this functional overlap, ANO1 has been considered to rescue the defective CFTR functions in cystic fibrosis (Becq et al, 2011; Sondo et al, 2014). CFTR is activated by ATP and PKA and has multiple transmembrane-spanning domains in the cell membrane and a regulatory domain and two nucleotide-binding domains in the cytosolic side (Hwang \& Sheppard, 2009). The binding of ATP to the nucleotide-binding domains is known to activate the CFTR while the phosphorylation of the regulatory domain by PKA is a prerequisite for the activation. Unlike the CFTR, ANO9 does not contain nucleotide-binding domains, and therefore ANO9 gating does not require ATP because it is not activated by ATP alone (Fig. 2B). However, whether the phosphorylation of ANO9 at Ser245 by PKA is indispensable or is a prerequisite for its activation remains unclear. ANO9 did not have a bulky regulatory domain with multiple phosphorylation sites as shown in the CFTR, which is the structural basis for the prerequisite requirement for activation. Because only the direct application of PKA along with cAMP and ATP activates ANO9, it is highly likely that ANO9 opens only when it is phosphorylated at Ser245 by PKA. One limitation of this hypothesis is the location of the Ser245 residue. When the location was predicted by the crystal structure of the homologous nhTMEM16 in the fungus 
Nectria haematococca, the Ser245 residue was located in the first extracellular loop. This location is difficult to reconcile as the PKA phosphorylation site of ANO9. However, the crystal structure was obtained with membrane-embedded crystals of nhTMEM16, which have only scramblase activity and not channel activity. Mouse ANO9 also has only $21 \%$ sequence homology with nhTMEM16. Therefore, the predicted location of the Ser245 residue in the homology modeling with nhTMEM16 might not represent the actual location in the mouse ANO9. To identify if Ser245 region is located in the intracellular region, we cloned an HA-tagged ANO9. If the N-terminal of ANO9 is in the extracellular region, then the Ser245 will be located in the intracellular loop. In live cell imaging, the HA epitope tagged $\mathrm{N}$-terminal was detected by an HA-antibody without detergent. These results provide strong evidence that the location of the $\mathrm{N}$-terminal of ANO9 is extracellular. 


\section{Material and methods}

\section{Cloning of mouse Ano9 and mutagenesis}

Primers were designed using the mouse cDNA sequences of Ano9 (TMEM16J) from the NCBI database (NM_178381.3). The cDNA encoding Ano9 has been isolated from the lung of adult C57BL/6J mice. The full-length coding sequence of Ano9 (Tmem16J; NM_178381.3) was amplified by PCR using site-specific primers:

forward primer 5'- GCCACCATGCAGGATGATGAGAGTTCCCAG-3', reverse primer 5'- GACCGGTCTATACATCCGTGCTCCTGGAAC-3'.

Ano9 were cloned into pEGFP-N1 to have fusion proteins tagged with EGFP. To express ANO9-GFP fusion protein, a stop codon was deleted from pEGFP-N1mANO1 using the Muta-Direct site directed mutagenesis kit (iNtRON Biotech). The protein sequence of mouse Ano9 (NP_848468.2) is

MQDDESSQIFMGPEGDQLPLVEMGSCKPEASDQWDCVLVADLQTLKIQKHAQ KQLQFLENLESNGFHFKMLKDQKKVFFGIRADSDVIDKYRTLLMNPEDSGSRDEQS FNIATTRIRIVSFVVNNKLKPGDTFEDLVKDGVFETMFLLHKGEQNLKNIWARWRNM FEPQPIDEIREYFGEKVALYFTWLGWYTYMLVPAAVVGLIVFLSGFALFDSSQISKEIC SANDIFMCPLGDHSHRYLRLSEMCTFAKLTHLFDNEGTVLFAIFMALWATVFLEIWKR KRAHEVQSWKLYEWDEEEEEMALELINSPHYKLKDHRHSYLSSTIILILSLFMICLMIG MAHVLVVYRVLAGALFSSLVKQQVTTAVVVTGAVVHYIIIVIMTKVNKYVALKLCKFEE SGTFSEQERKFTVKFFILQFFAHFSSLIYIAFILGRINGHPGKSTRLAGLWKLEECHLS GCMMDLFIQMAIIMGLKQTLSNCVEYLCPLLAHKWRLMWASKHGHMSKDPELKEW QRNYYMNPINTFSLFDEFMEMMIQYGFTTIFVAAFPLAPLLALFSNLVEIRLDAIKMVR LQRRLVPRKAKDIGTWLQVLETIGVLAVIANGMVIAFTSEFIPRVVYKYHYGPCRTNR 


\section{TFTDDCLTNYVNHSLSVFYTKHFNDHSRMEGQENVTVCRYRDYRNEHDYNLSEQF} WFILAIRLTFVILFEHFALCIKLIAAWFVPDVPQKVKNEVLQEKYDRIRHRMRFSSRST DV.

All mutants were generated from the wild-type mouse Ano9 construct tagged with eGFP (pEGFP-N1-mANO9). The amino acid substitution mutants were constructed using a site-directed mutagenesis kit. The construction of mutants was verified with DNA sequencing. To generate HA-tagged mAno9 mutants, haemagglutinin (HA) epitopes (YPYDVPDYA) were added to the N-terminus of mAno9 using the HApcDNA3.1 vector.

The HA epitopes next to the Ser245 residue in mAno9 were introduced by sitedirected mutagenesis. The insertion was repeated four times with each set of primers.

$1^{\text {st }}$ forward primer : $5^{\prime}$-gatacctgcgactctcatacccatgagatgtgcactttcgc-3', $1^{\text {st }}$ reverse primer : 5'-gcgaaagtgcacatctcatgggtatgagagtcgcaggtatc-3',

$2^{\text {nd }}$ forward primer : 5'-gcgactctcatacccatacgatgtgagatgtgcactttcg-3', $2^{\text {nd }}$ reverse primer 5'-cgaaagtgcacatctcacatcgtatgggtatgagagtcgc-3',

$3^{\text {rd }}$ forward primer : 5'-tcatacccatacgatgttccagatgagatgtgcactttcgc-3', $3^{\text {rd }}$ reverse primer : 5'-gcgaaagtgcacatctcatctggaacatcgtatgggtatga-3',

$4^{\text {th }}$ forward primer : $5^{\prime}$-tcatacccatacgatgttccagattacgctgagatgtgcactt-3', $4^{\text {th }}$ reverse primer : 5'-aagtgcacatctcagcgtaatctggaacatcgtatgggtatga-3'.

\section{Cell culture and transfection of Ano9}

Cell culture and functional expression of ANO9 or mutants were performed in HEK 293T cells. HEK $293 \mathrm{~T}$ cells were maintained at $5 \% \mathrm{CO}_{2}$, and incubated at $37^{\circ} \mathrm{C}$ in Dulbecco's modified Eagle's medium (DMEM) supplemented with $10 \%$ fetal bovine 
serum (FBS), 10 units/mL penicillin and $10 \mu \mathrm{g} / \mathrm{mL}$ streptomycin. To induce ANO9 expression in HEK293T cells, cells were transfected with mAno9 cDNA mixed with the FuGene HD (Roche Diagnostics) transfection reagent. The transfected cells were plated onto glass coverslips. The current responses were recorded 24 to $48 \mathrm{~h}$ after transfection.

\section{Whole-cell and single-channel current recordings}

Whole-cell and single-channel current recordings were obtained using either a voltage-clamp technique with an Axopatch 200B amplifier (Molecular Devices) as descried previously (Cho et al, 2012; Lee et al, 2015). Briefly, whole-cell currents were measured after breaking the plasma membrane under the pipette tips. The resistance of the glass pipettes was about $3 \mathrm{~m} \Omega$. The junctional potentials were cancelled to zero. Unless otherwise stated, the bath solution contained (in mM) $140 \mathrm{NaCl}, 2 \mathrm{CaCl}_{2}, 2$ $\mathrm{MgCl}_{2}$ and $10 \mathrm{NaOH}-\mathrm{HEPES}$ adjusted to $\mathrm{pH}$ 7.2. The pipette solution contained (in mM) $140 \mathrm{KCl}, 2 \mathrm{CaCl}_{2}, 2 \mathrm{MgCl}_{2}$ and $10 \mathrm{KOH}$-HEPES adjusted to $\mathrm{pH} 7.2$.

For inside-out patch recording, after a giga-seal was formed, the glass pipette was pulled quickly from the cell to isolate a membrane patch. The output of the amplifier was fed to an analog/digital converter (Digidata 1440, Molecular Devices) and stored in a personal computer. The pClamp 10 software was used for I-V curve and other biophysical analysis.

$\mathrm{Ca}^{2+}$ was chelated with $10 \mathrm{mM}$ EGTA and $10 \mathrm{mM}$ HEDTA to make the free 1.0 and $10 \mu \mathrm{M} \mathrm{Ca}^{2+}$ in the pipette solutions, respectively. The free $\mathrm{Ca}^{2+}$ was calculated using WEBMAXC (http://www.stanford.edu/ cpatton/webmaxcS.htm). 


\section{Immunofluorescent staining}

SW480 cells were fixed on glass coverslips in $4 \%$ paraformaldehyde for $10 \mathrm{~min}$ at room temperature, permeabilized with $0.2 \%$ Triton $\mathrm{X}-100$, and incubated with antiANO9 antibody (dilution 1:200, LS-C179041, LifeSpan BioSciences, Inc.) overnight at $4^{\circ} \mathrm{C}$. The coverslips were washed and incubated with the Alexa Fluor 488-tagged donkey-anti-mouse IgG (1:1000, Molecular Probes, CA). For nuclear staining, SW480 cells and HEK293T cells were incubated with Hoechst 33342 (H3570, Thermofisher Scientific, 1:2,000) after ANO9 immunostaining

For HA staining, HEK293T cells transfected with the HA-tagged Ano9 mutants were incubated with anti-HA antibody (1:100, Cat\# H6905, Sigma-Aldrich) for $1 \mathrm{hr}$ at room temperature. The cells were then washed three times and incubated with the Alexa Fluor 488 goat-anti-rabbit IgG (1:200, Life Technologies Cat\# A11008) for 30 min at room temperature. Finally, the cells were washed and fixed with $4 \%$ PFA. For permeabilized staining, cells were fixed with $4 \%$ PFA and treated with $0.2 \%$ Triton 100 for $10 \mathrm{~min}$. Then, the cells were incubated with the anti-HA antibody (1:100) for $1 \mathrm{hr}$, washed three times, and then incubated with the Alexa Fluor 488 goat-anti-rabbit IgG for $30 \mathrm{~min}$ at room temperature. After washing, the coverslips were mounted and imaged using a confocal microscopy.

\section{Small interfering RNA (siRNA) treatment}

Two nucleotide oligomer siRNAs targeting mouse ANO9 or scrambled siRNA labelled with Cy3 were provided by Bioneer (Seoul, Korea) transfected into cells using 
Lipofectamine $2000^{\mathrm{TM}}$ (Invitrogen) 1 day after plating. We transfected the cells with a mixture of the two siRNAs simultaneously for maximal effect. The two siRNAs (Nos. 1152997 and 1152999) are as follows.

1152997 Sense: GUGAACUUCGUUGUCAUGA(dTdT), 1152997 Antisense: UCAUGACAACGAAGUUCAC(dTdT),

1152999 Sense: UCAGCAACUGCGUCGAGUA(dTdT), 1152999 Antisense: UACUCGACGCAGUUGCUGA(dTdT).

\section{Calcium imaging}

ANO9-HEK cells or HEK293T cells transfected with S245A Ano9 mutant were loaded with Fluo3-AM (Invitrogen) containing 0.1\% Pluronic F-127 (Invitrogen). After loading with Fluo3-AM for 40 min, db-cAMP alone or with H89 was applied to the cells. The fluorescence intensities of cells were measured at $488 \mathrm{~nm}$ in every $5 \mathrm{~s}$ with a confocal microscope (LSM700, Zeiss).

\section{Real-time quantitative PCR}

Major mouse organs were isolated from three 7-week-old mice. The total RNAs from each organ were purified with ethanol precipitation or the Easy Spin ${ }^{\mathrm{TM}}$ Total RNA Extraction Kit (iNtROn Biotech) according to the manufacturer's protocol. The first strand cDNAs were reverse transcribed from the total RNA using the Transcriptor First Strand cDNA Synthesis Kit (Roche). To measure the gene expression level, we performed real-time quantitative PCR (qPCR) in the LightCycler 2.0 system (Roche) using an ANO9 specific universal probe (forward primer: cggactctcctcatgaatcc; reverse primer: tgttcacgacaaagctcaca). The absolute copy numbers per $250 \mathrm{ng}$ of total RNA 
were calculated using the absolute quantification with the external standard method in the Light Cycler software 4.0.

\section{Reagents}

The Anti-ANO9/TMEM16J antibody (aa81-224) LS-C179041 was purchased from Lifespan Biosciences Inc, We purchased adenosine 3',5'-cyclic monophosphate (cAMP; A9501), cholera toxin from Vibrio cholera (CTX; C8052), N6,2'-Odibutyryladenosine $3^{\prime}, 5^{\prime}$-cyclic monophosphate (db-cAMP) sodium salt (D0627), protein kinase A from bovine heart (PKA; P5511), H-89 dihydrochloride hydrate (B1427), and H-7 dihydrochloride (I7016) from Sigma-Aldrich. All basic chemicals for the electrophysiology experiments were also purchased from Sigma- Aldrich.

\section{Statistical analysis}

All results are expressed as means \pm standard errors (S.E.). The statistical significances of the differences were determined by a one-way analysis of variance (ANOVA) followed by the Tukey's post-hoc test for multiple comparisons. Statistical significance was accepted at $p$ values of less than 0.05 . 


\section{References}

Becq F, Mall MA, Sheppard DN, Conese M, Zegarra-Moran O (2011) Pharmacological therapy for cystic fibrosis: from bench to bedside. Journal of cystic fibrosis : official journal of the European Cystic Fibrosis Society 10 Suppl 2: S129-145. doi: 10.1016/s1569-1993(11)60018-0.

Bernstein K, Vink JY, Fu XW, Wakita H, Danielsson J, Wapner R, Gallos G (2014) Calcium-activated chloride channels anoctamin 1 and 2 promote murine uterine smooth muscle contractility. American journal of obstetrics and gynecology 211: 688.e681-610. doi: 10.1016/j.ajog.2014.06.018.

Billig GM, Pal B, Fidzinski P, Jentsch TJ (2011) Ca2+-activated Cl- currents are dispensable for olfaction. Nature neuroscience 14: 763-769. doi: 10.1038/nn.2821.

Britschgi A, Bill A, Brinkhaus H, Rothwell C, Clay I, Duss S, Rebhan M, Raman P, Guy CT, Wetzel K, George E, Popa MO, Lilley S, Choudhury H, Gosling M, Wang L, Fitzgerald S, Borawski J, Baffoe J, Labow M, Gaither LA, Bentires-Alj M (2013) Calcium-activated chloride channel ANO1 promotes breast cancer progression by activating EGFR and CAMK signaling. Proceedings of the National Academy of Sciences of the United States of America 110: E1026-1034. doi: 10.1073/pnas.1217072110.

Brunner JD, Lim NK, Schenck S, Duerst A, Dutzler R (2014) X-ray structure of a calcium-activated TMEM16 lipid scramblase. Nature 516: 207-212. doi: 10.1038/nature13984.

Bulley S, Neeb ZP, Burris SK, Bannister JP, Thomas-Gatewood CM, Jangsangthong W, Jaggar JH (2012) TMEM16A/ANO1 channels contribute to the myogenic response in cerebral arteries. Circ Res 111: 1027-1036. doi: 10.1161/CIRCRESAHA.112.277145.

Caputo A, Caci E, Ferrera L, Pedemonte N, Barsanti C, Sondo E, Pfeffer U, Ravazzolo R, ZegarraMoran O, Galietta LJ (2008) TMEM16A, a membrane protein associated with calcium-dependent chloride channel activity. Science 322: 590-594. doi: 10.1126/science.1163518.

Castoldi E, Collins PW, Williamson PL, Bevers EM (2011) Compound heterozygosity for 2 novel TMEM16F mutations in a patient with Scott syndrome. Blood 117: 4399-4400. doi: 10.1182/blood- 
2011-01-332502.

Cenedese V, Betto G, Celsi F, Cherian OL, Pifferi S, Menini A (2012) The voltage dependence of the TMEM16B/anoctamin2 calcium-activated chloride channel is modified by mutations in the first putative intracellular loop. The Journal of general physiology 139: 285-294. doi: 10.1085/jgp.201110764.

Cha JY, Wee J, Jung J, Jang Y, Lee B, Hong GS, Chang BC, Choi YL, Shin YK, Min HY, Lee HY, Na TY, Lee MO, Oh $U$ (2015) Anoctamin 1 (TMEM16A) is essential for testosterone-induced prostate hyperplasia. Proceedings of the National Academy of Sciences of the United States of America 112: 9722-9727. doi: 10.1073/pnas.1423827112.

Cho H, Yang YD, Lee J, Lee B, Kim T, Jang Y, Back SK, Na HS, Harfe BD, Wang F, Raouf R, Wood JN, Oh $U$ (2012) The calcium-activated chloride channel anoctamin 1 acts as a heat sensor in nociceptive neurons. Nature neuroscience 15: 1015-1021. doi: 10.1038/nn.3111.

Cobine CA, Hannah EE, Zhu MH, Lyle HE, Rock JR, Sanders KM, Ward SM, Keef KD (2017) ANO1 in intramuscular interstitial cells of Cajal plays a key role in the generation of slow waves and tone in the internal anal sphincter. J Physio/ 595: 2021-2041. doi: 10.1113/jp273618.

Dauner K, Mobus C, Frings S, Mohrlen F (2013) Targeted expression of anoctamin calcium-activated chloride channels in rod photoreceptor terminals of the rodent retina. Investigative ophthalmology \& visual science 54: 3126-3136. doi: 10.1167/iovs.13-11711.

Duvvuri U, Shiwarski DJ, Xiao D, Bertrand C, Huang X, Edinger RS, Rock JR, Harfe BD, Henson BJ, Kunzelmann K, Schreiber R, Seethala RS, Egloff AM, Chen X, Lui VW, Grandis JR, Gollin SM (2012) TMEM16A induces MAPK and contributes directly to tumorigenesis and cancer progression. Cancer research 72: 3270-3281. doi: 10.1158/0008-5472.can-12-0475-t.

Forrest AS, Angermann JE, Raghunathan R, Lachendro C, Greenwood IA, Leblanc N (2010) Intricate interaction between store-operated calcium entry and calcium-activated chloride channels in pulmonary artery smooth muscle cells. Advances in experimental medicine and biology 661: 31-55. doi: 10.1007/978-1-60761-500-2_3. 
Gabriel SE, Brigman KN, Koller BH, Boucher RC, Stutts MJ (1994) Cystic fibrosis heterozygote resistance to cholera toxin in the cystic fibrosis mouse model. Science 266: 107-109. doi: 10.1126/science.7524148.

Hille B (2001) Selective Permeability: Independence. In Ion Channels of Excitable Membranes, Hille B (ed), 3rd edn, 14, pp 441-470. Sunderland: Sinauer Associate

Hu Y, Kim JH, He K, Wan Q, Kim J, Flach M (2016) Scramblase TMEM16F terminates T cell receptor signaling to restrict $T$ cell exhaustion. The Journal of experimental medicine 213: 2759-2772. doi: 10.1084/jem.20160612.

Huang F, Wang X, Ostertag EM, Nuwal T, Huang B, Jan YN, Basbaum Al, Jan LY (2013) TMEM16C facilitates $\mathrm{Na}(+)$-activated $\mathrm{K}+$ currents in rat sensory neurons and regulates pain processing. Nature neuroscience 16: 1284-1290. doi: 10.1038/nn.3468.

Huang F, Zhang H, Wu M, Yang H, Kudo M, Peters CJ, Woodruff PG, Solberg OD, Donne ML, Huang X, Sheppard D, Fahy JV, Wolters PJ, Hogan BL, Finkbeiner WE, Li M, Jan YN, Jan LY, Rock JR (2012a) Calcium-activated chloride channel TMEM16A modulates mucin secretion and airway smooth muscle contraction. Proceedings of the National Academy of Sciences of the United States of America 109: 16354-16359. doi: 10.1073/pnas.1214596109.

Huang WC, Xiao S, Huang F, Harfe BD, Jan YN, Jan LY (2012b) Calcium-activated chloride channels (CaCCs) regulate action potential and synaptic response in hippocampal neurons. Neuron 74: 179192. doi: 10.1016/j.neuron.2012.01.033.

Hwang SJ, Blair PJ, Britton FC, O'Driscoll KE, Hennig G, Bayguinov YR, Rock JR, Harfe BD, Sanders KM, Ward SM (2009) Expression of anoctamin 1/TMEM16A by interstitial cells of Cajal is fundamental for slow wave activity in gastrointestinal muscles. The Journal of physiology 587: 4887-4904. doi: 10.1113/jphysiol.2009.176198.

Hwang TC, Sheppard DN (2009) Gating of the CFTR Cl- channel by ATP-driven nucleotide-binding domain dimerisation. The Journal of physiology 587: 2151-2161. doi: 10.1113/jphysiol.2009.171595.

Jang Y, Oh U (2014) Anoctamin 1 in secretory epithelia. Cell Calcium 55: 355. doi: 
10.1016/j.ceca.2014.02.006.

Jia L, Liu W, Guan L, Lu M, Wang K (2015) Inhibition of Calcium-Activated Chloride Channel ANO1/TMEM16A Suppresses Tumor Growth and Invasion in Human Lung Cancer. PLoS One 10: e0136584. doi: 10.1371/journal.pone.0136584.

Katoh M, Katoh M (2003) FLJ10261 gene, located within the CCND1-EMS1 locus on human chromosome 11q13, encodes the eight-transmembrane protein homologous to C12orf3, C11orf25 and FLJ34272 gene products. Int J Onco/ 22: 1375-1381. doi: 10.3892/ijo.22.6.1375.

Keckeis S, Reichhart N, Roubeix C, Strauss O (2017) Anoctamin2 (TMEM16B) forms the Ca2+activated $\mathrm{Cl}$ - channel in the retinal pigment epithelium. Experimental eye research 154: 139-150. doi: 10.1016/j.exer.2016.12.003.

Lee J, Jung J, Tak MH, Wee J, Lee B, Jang Y, Chun H, Yang DJ, Yang YD, Park SH, Han BW, Hyun S, Yu J, Cho H, Hartzell HC, Oh U (2015) Two helices in the third intracellular loop determine anoctamin 1 (TMEM16A) activation by calcium. Pflugers Arch 467: 1677-1687. doi: 10.1007/s00424-014-16032.

Li C, Cai S, Wang X, Jiang Z (2015) Identification and characterization of ANO9 in stage II and III colorectal carcinoma. Oncotarget 6: 29324-29334. doi: 10.18632/oncotarget.4979.

Malvezzi M, Chalat M, Janjusevic R, Picollo A, Terashima H, Menon AK, Accardi A (2013) Ca2+dependent phospholipid scrambling by a reconstituted TMEM16 ion channel. Nature communications 4: 2367. doi: 10.1038/ncomms3367.

Namkung W, Phuan PW, Verkman AS (2011) TMEM16A inhibitors reveal TMEM16A as a minor component of calcium-activated chloride channel conductance in airway and intestinal epithelial cells. J Biol Chem 286: 2365-2374. doi: 10.1074/jbc.M110.175109.

Neureither F, Ziegler K, Pitzer C, Frings S (2017) Impaired Motor Coordination and Learning in Mice Lacking Anoctamin 2 Calcium-Gated Chloride Channels. Cerebellum (London, England): pp 1-9. doi: 10.1007/s12311-017-0867-4. 
Ousingsawat J, Martins JR, Schreiber R, Rock JR, Harfe BD, Kunzelmann K (2009) Loss of TMEM16A causes a defect in epithelial Ca2+-dependent chloride transport. J Bio/ Chem 284: 28698-28703. doi: 10.1074/jbc.M109.012120.

Picollo A, Malvezzi M, Accardi A (2015) TMEM16 proteins: unknown structure and confusing functions. Journal of molecular biology 427: 94-105. doi: 10.1016/j.jmb.2014.09.028.

Pietra G, Dibattista M (2016) The Ca2+-activated Cl- channel TMEM16B regulates action potential firing and axonal targeting in olfactory sensory neurons. The Journal of general physiology 148: 293-311. doi: 10.1085/jgp.201611622.

Pifferi S, Dibattista M, Menini A (2009) TMEM16B induces chloride currents activated by calcium in mammalian cells. Pflugers Arch 458: 1023-1038. doi: 10.1007/s00424-009-0684-9.

Rock JR, Harfe BD (2008) Expression of TMEM16 paralogs during murine embryogenesis. Developmental dynamics : an official publication of the American Association of Anatomists 237: 2566-2574. doi: 10.1002/dvdy.21676.

Romanenko VG, Catalan MA, Brown DA, Putzier I, Hartzell HC, Marmorstein AD, Gonzalez-Begne M, Rock JR, Harfe BD, Melvin JE (2010) Tmem16A encodes the Ca2+-activated Cl- channel in mouse submandibular salivary gland acinar cells. J Biol Chem 285: 12990-13001. doi: 10.1074/jbc.M109.068544.

Schreiber R, Faria D, Skryabin BV, Wanitchakool P, Rock JR, Kunzelmann K (2015) Anoctamins support calcium-dependent chloride secretion by facilitating calcium signaling in adult mouse intestine. Pflugers Arch 467: 1203-1213. doi: 10.1007/s00424-014-1559-2.

Schreiber R, Uliyakina I, Kongsuphol P, Warth R, Mirza M, Martins JR, Kunzelmann K (2010) Expression and function of epithelial anoctamins. J Bio/ Chem 285: 7838-7845. doi: 10.1074/jbc.M109.065367.

Schroeder BC, Cheng T, Jan YN, Jan LY (2008) Expression cloning of TMEM16A as a calcium-activated chloride channel subunit. Cel/ 134: 1019-1029. doi: 10.1016/j.cell.2008.09.003. 
Sondo E, Caci E, Galietta LJ (2014) The TMEM16A chloride channel as an alternative therapeutic target in cystic fibrosis. The international journal of biochemistry \& cell biology 52: 73-76. doi: 10.1016/j.biocel.2014.03.022.

Stephan AB, Shum EY, Hirsh S, Cygnar KD, Reisert J, Zhao H (2009) ANO2 is the cilial calciumactivated chloride channel that may mediate olfactory amplification. Proceedings of the National Academy of Sciences of the United States of America 106: 11776-11781. doi: 10.1073/pnas.0903304106.

Suzuki J, Umeda M, Sims PJ, Nagata S (2010) Calcium-dependent phospholipid scrambling by TMEM16F. Nature 468: 834-838. doi: 10.1038/nature09583.

Tran TT, Tobiume K, Hirono C, Fujimoto S, Mizuta K, Kubozono K, Inoue H, Itakura M, Sugita M, Kamata N (2014) TMEM16E (GDD1) exhibits protein instability and distinct characteristics in chloride channel/pore forming ability. Journal of cellular physiology 229: 181-190. doi: 10.1002/jcp.24431.

Xiao Q, Yu K, Perez-Cornejo P, Cui Y, Arreola J, Hartzell HC (2011) Voltage- and calcium-dependent gating of TMEM16A/Ano1 chloride channels are physically coupled by the first intracellular loop. Proceedings of the National Academy of Sciences of the United States of America 108: 8891-8896. doi: 10.1073/pnas.1102147108.

Xu C, Gagnon E, Call ME, Schnell JR, Schwieters CD, Carman CV, Chou JJ, Wucherpfennig KW (2008) Regulation of $\mathrm{T}$ cell receptor activation by dynamic membrane binding of the CD3epsilon cytoplasmic tyrosine-based motif. Cel/ 135: 702-713. doi: 10.1016/j.cell.2008.09.044.

Xue Y, Ren J, Gao X, Jin C, Wen L, Yao X (2008) GPS 2.0, a Tool to Predict Kinase-specific Phosphorylation Sites in Hierarchy. Molecular \& Cellular Proteomics : MCP 7: 1598-1608. doi: 10.1074/mcp.M700574-MCP200.

Yang H, Kim A, David T, Palmer D, Jin T, Tien J, Huang F, Cheng T, Coughlin SR, Jan YN, Jan LY (2012) TMEM16F forms a Ca2+-activated cation channel required for lipid scrambling in platelets during blood coagulation. Cel/ 151: 111-122. doi: 10.1016/j.cell.2012.07.036. 
Yang YD, Cho H, Koo JY, Tak MH, Cho Y, Shim WS, Park SP, Lee J, Lee B, Kim BM, Raouf R, Shin YK, Oh U (2008) TMEM16A confers receptor-activated calcium-dependent chloride conductance. Nature 455: 1210-1215. doi: 10.1038/nature07313.

Zhang H, Cordoba SP, Dushek O, van der Merwe PA (2011) Basic residues in the T-cell receptor zeta cytoplasmic domain mediate membrane association and modulate signaling. Proc Natl Acad Sci U S A 108: 19323-19328. doi: 10.1073/pnas.1108052108.

Zhang W, Schmelzeisen S, Parthier D, Frings S, Mohrlen F (2015) Anoctamin Calcium-Activated Chloride Channels May Modulate Inhibitory Transmission in the Cerebellar Cortex. PLoS One 10: e0142160. doi: 10.1371/journal.pone.0142160. 


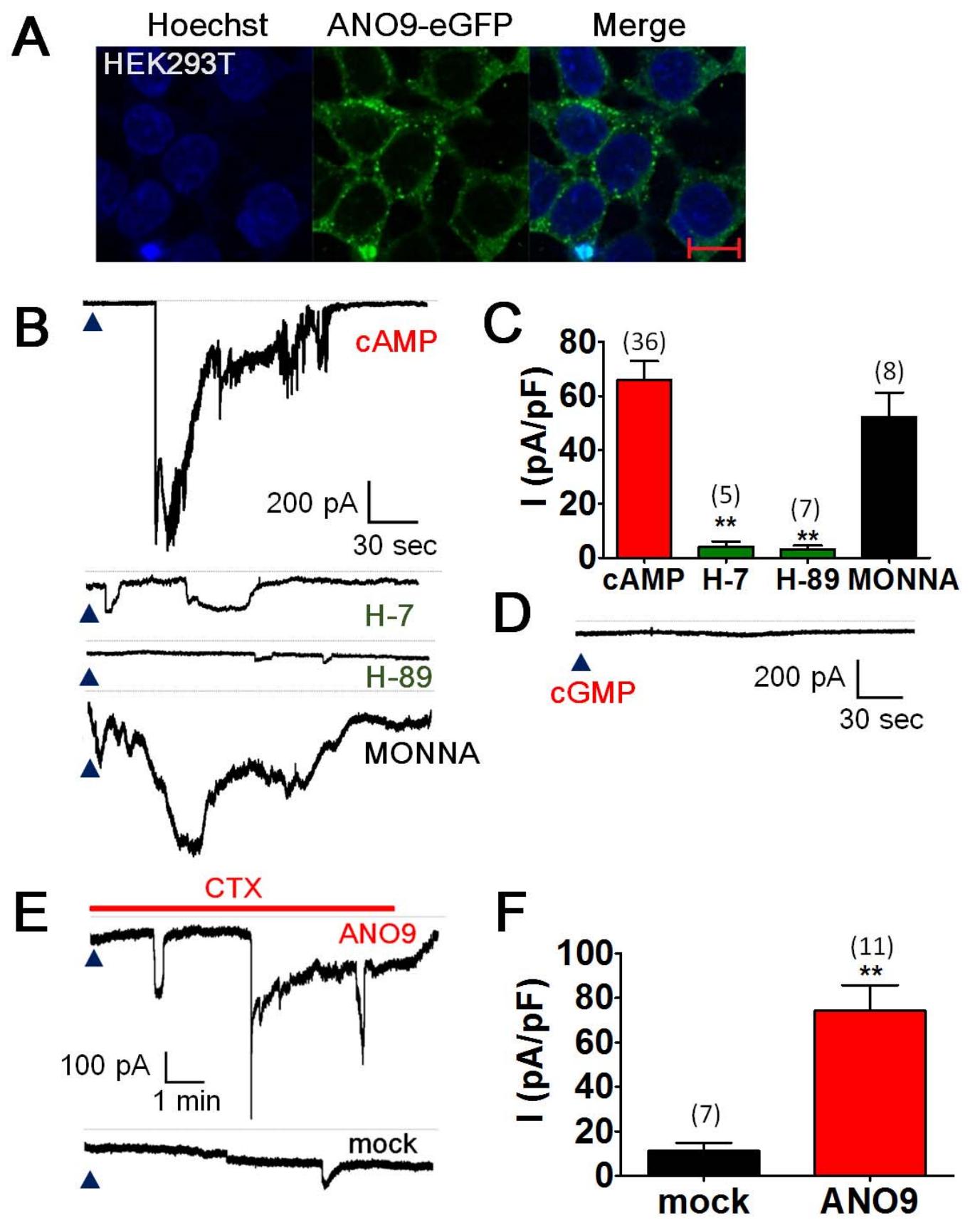

Figure 1. Intracellular cAMP activates ANO9.

(A) The overexpression of mANO9-pEGFP-N1 in the HEK293T cells with Hoechst 33342 staining (left).

(B) Representative traces of whole-cell currents of HEK293T cells transfected with Ano9. The bath solution contained (in $\mathrm{mM}) 140 \mathrm{NaCl}, 2 \mathrm{MgCl}_{2}$ and $2 \mathrm{CaCl}_{2}$ buffered with $10 \mathrm{HEPES}$, and the pipette solution contained $140 \mathrm{KCl}, 2 \mathrm{MgCl}_{2}, 2$ ATP, 0.3 GTP buffered with $10 \mathrm{mM}$ HEPES. CAMP $(100 \mu \mathrm{M})$ was added to the pipette solution. Ehold $=-60 \mathrm{mV}$. Note that intracellular cAMP evoked robust inward currents in the ANO9-HEK cells but not in the $\mathrm{H}-7$ and $\mathrm{H}-89$ pre-treated cells. The pretreatment of an ANO1-antagonist, MONNA, failed to block the CAMP-induced ANO9 current. The dashed lines represent zero current. Arrow head represents the time for forming a whole cell.

(C) Summary of the cAMP-induced whole-cell currents of control (cAMP) and the H-7, H-89, MONNA pre-treated ANO9HEK cells. The error bars represent S.E.M. ${ }^{* *} p<0.01$, one way ANOVA followed by Tukey's post-hoc test. Numbers in parenthesis represent the experimental numbers.

(D) A representative trace of whole-cell currents of ANO9-HEK cells with $100 \mu \mathrm{M}$ cGMP in the pipette solution.

(E) The cholera toxin (CTX) applied to the bath evoked whole-cell inward currents in ANO9-HEK cells but not in mocktransfected HEK293T cells.

(F) Summary of the CTX-induced currents in ANO9-HEK cells. 
A

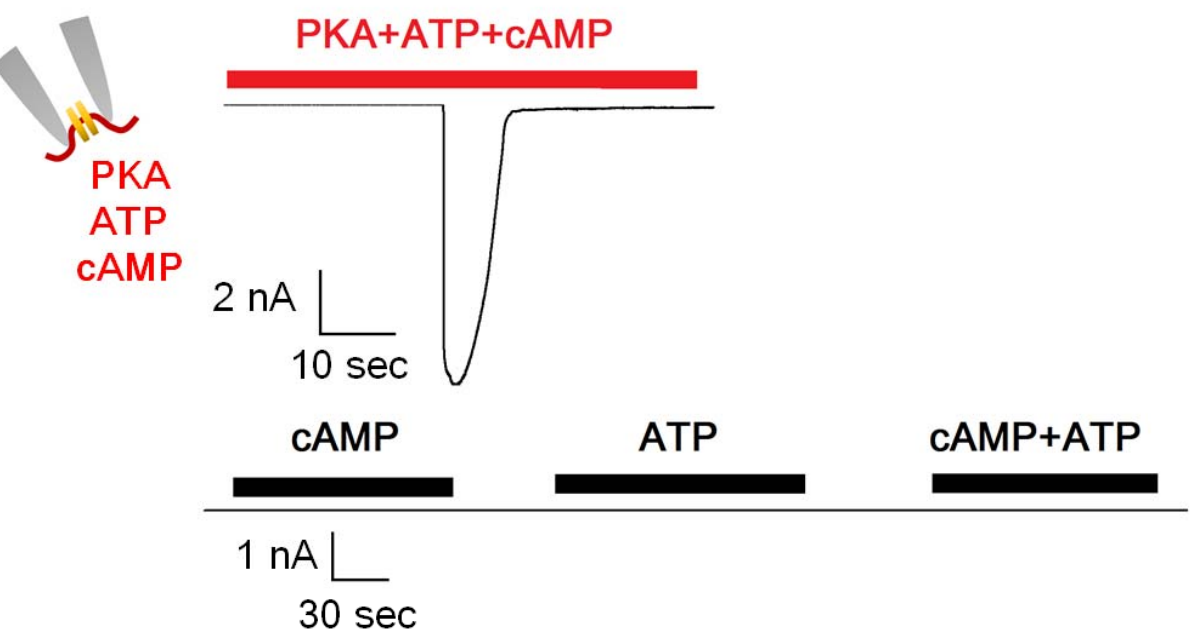

B

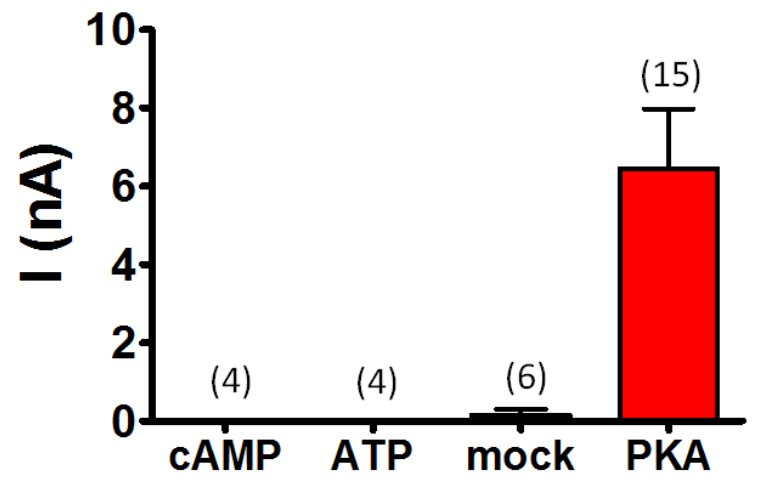

Figure 2. The phosphorylation by PKA activates ANO9.

(A) Representative traces of macroscopic currents of inside-out membrane patches from ANO-HEK cells. The application of purified PKA proteins $(7$ units $/ \mathrm{ml})$ together with $100 \mu \mathrm{M}$ cAMP and $2 \mathrm{mM}$ ATP to the bath evoked a robust current (upper) whereas the application of CAMP and ATP alone failed to evoke the macroscopic currents.

(B) Summary of the PKA-evoked currents in ANO9-HEK cells in inside-out patch configuration. 
A

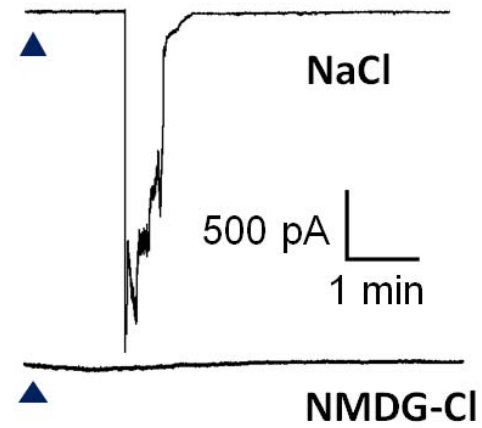

B

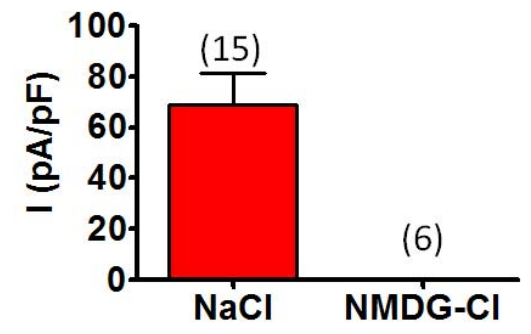

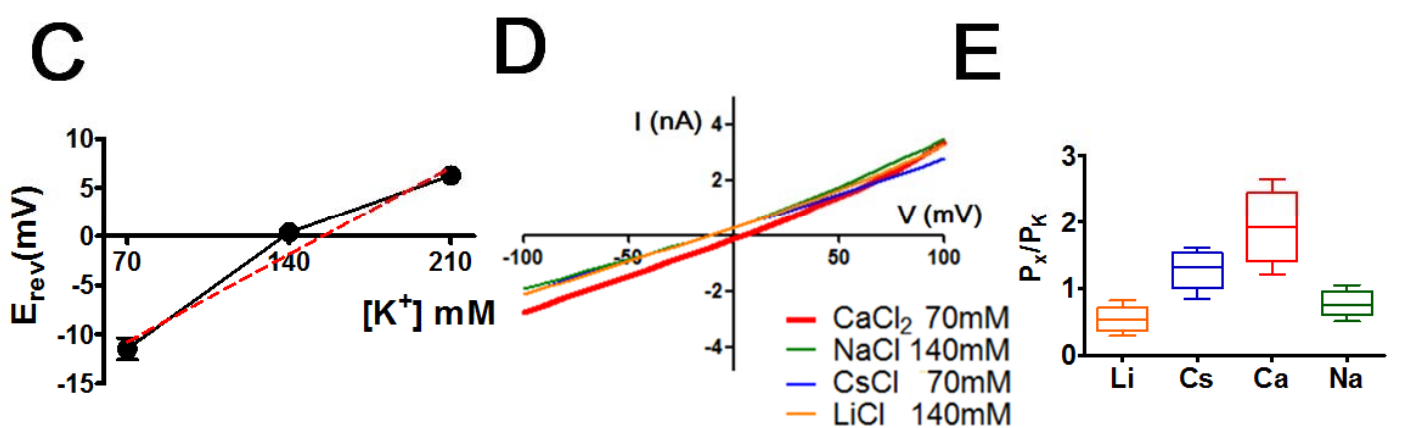
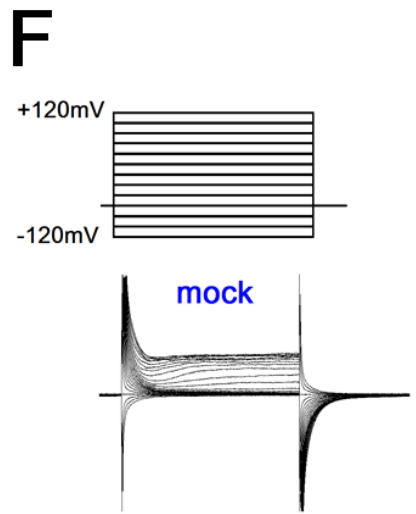

$1 \mathrm{nA}$ $10 \mathrm{~ms}$

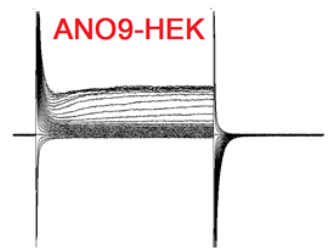

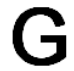

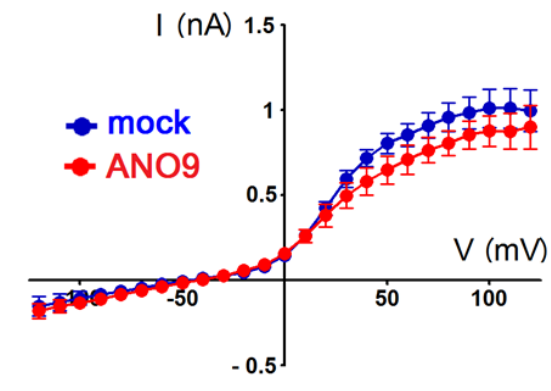

Figure 3. ANO9 is a cation channel.

(A) Whole-cell currents of ANO9-HEK cells activated by $100 \mu \mathrm{M}$ cAMP in $140 \mathrm{mM} \mathrm{NaCl}$ (upper) but not in $140 \mathrm{mM}$ NMDG$\mathrm{Cl}$ (lower) bath solutions.

(B) The average current densities of ANO9-HEK cells activated by the intracellular CAMP at $\mathrm{NaCl}$ or NMDG-Cl solution condition.

(C) Reversal potentials in different $\mathrm{KCl}$ concentration gradients between pipette and bath solutions. Reversal potentials were measured under bi-ionic conditions where the pipette contained $140 \mathrm{mM} \mathrm{KCl}$ whereas the bath contained 70,140 or $210 \mathrm{mM} \mathrm{KCl} . \mathrm{n}=8$

(D-E) Cation selectivity of cAMP-induced ANO9 currents. Representative I-V curves (D) and the permeability ratios $\left(P_{x} / P_{K}\right)$ (E) of ANO9 currents. Whole cells were formed with the pipette contained $140 \mathrm{mM} \mathrm{KCl}$. Current-voltage relationship were obtained after the bath solution was changed to $70 \mathrm{mM} \mathrm{CaCl}_{2}, 140 \mathrm{mM} \mathrm{NaCl}, 70 \mathrm{mM} \mathrm{CsCl}$, and $140 \mathrm{mM} \mathrm{LiCl}$. The permeability ratios, $P_{x} / P_{k}$ was calculated using the Goldman-Hodgkin-Katz equation.

(F-G) Whole-cell currents $(F)$ and the I-V curves of ANO9-HEK cells elicited by voltage steps. Voltage steps from -120 to $+120 \mathrm{mV}$ in $20 \mathrm{mV}$ increment were applied to whole cells of HEK cells transfected with vector alone (mock) or Ano9 (ANO9-HEK). 
bioRxiv preprint doi: https://doi.org/10.1101/188243; this version posted September 13, 2017. The copyright holder for this preprint (which was not certified by peer review) is the author/funder, who has granted bioRxiv a license to display the preprint in perpetuity. It is made
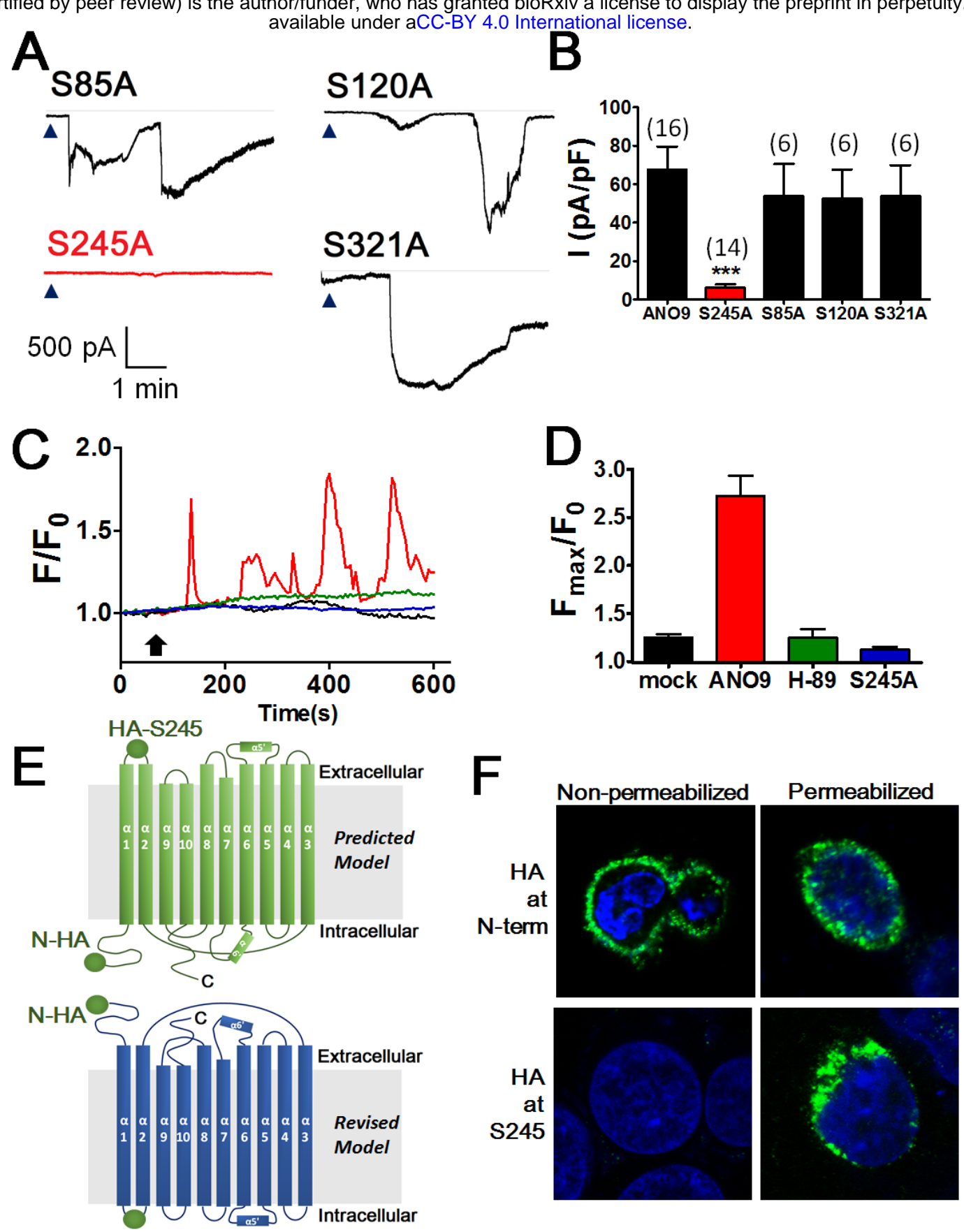

HA-S245

Figure 4. Phosphorylation at Ser245 is essential for ANO9 activity.

(A-B) Representative (A) and summary (B) of whole-cell currents of HEK293T cells transfected with ANO9 and its mutants. Putative PKA consensus sites were mutated. Each mutant was transfected to HEK293T cells. Intracellular cAMP evoked robust inward currents in the S85A, S120A and S321A-HEK cells but not in the S245A-HEK cells. ${ }^{* * *} p<0.001$, one way of ANOVA, Tukey's post-hoc test.

(C-D) Representative traces (C) and summary (D) of $\mathrm{Ca}^{2+}$ spikes of ANO9- or S245A mutant-transfected HEK293T cells after the application (arrow) of $2 \mathrm{mM}$ dbcAMP. Cells were incubated with $1 \mu \mathrm{M}$ Fluo3-AM. Note that the application of dbcAMP evoked $\mathrm{Ca}^{2+}$ spikes in ANO9-HEK cells but not in S245A-HEK or H-89-pretreated ANO9-HEK cells.

(E) The predicted topology model of ANO9 extracted from the crystal structure of nhTMEM16 (upper). Bottom image is a revised topology of mANO9. The revised model of mANO9 topology is based on the location of the N-terminus and S245.

(F) The immunofluorescent images of hemagglutinin (HA)-tagged Ano9-expressing HEK cells. HA epitope tag was inserted at the $\mathrm{N}$-terminal or at Ser245. The live cells were stained with an antibody for the HA epitope. When the HA was tagged at the Nterminus of ANO9, the HA-tagged ANO9-HEK cells were immunostained with the HA antibody whether the cells were permeabilized by Triton X-100 or not (non-permeabilized), indicating its location at the extracellular side. However, when the HA epitope was inserted next to the S245 residue, the HA-tagged ANO9-HEK cells were immunostained only when the cells were permeabilized with Triton $\mathrm{X}-100$, suggesting its location at the intracellular side. 
bioRxiv preprint doi: https://doi.org/10.1101/188243; this version posted September 13,2017 . The copyright holder for this preprint (which was not certified by peer review) is the author/funder, who has granted bioRxiv a license to display the preprint in perpetuity. It is made available under aCC-BY 4.0 International license.

A
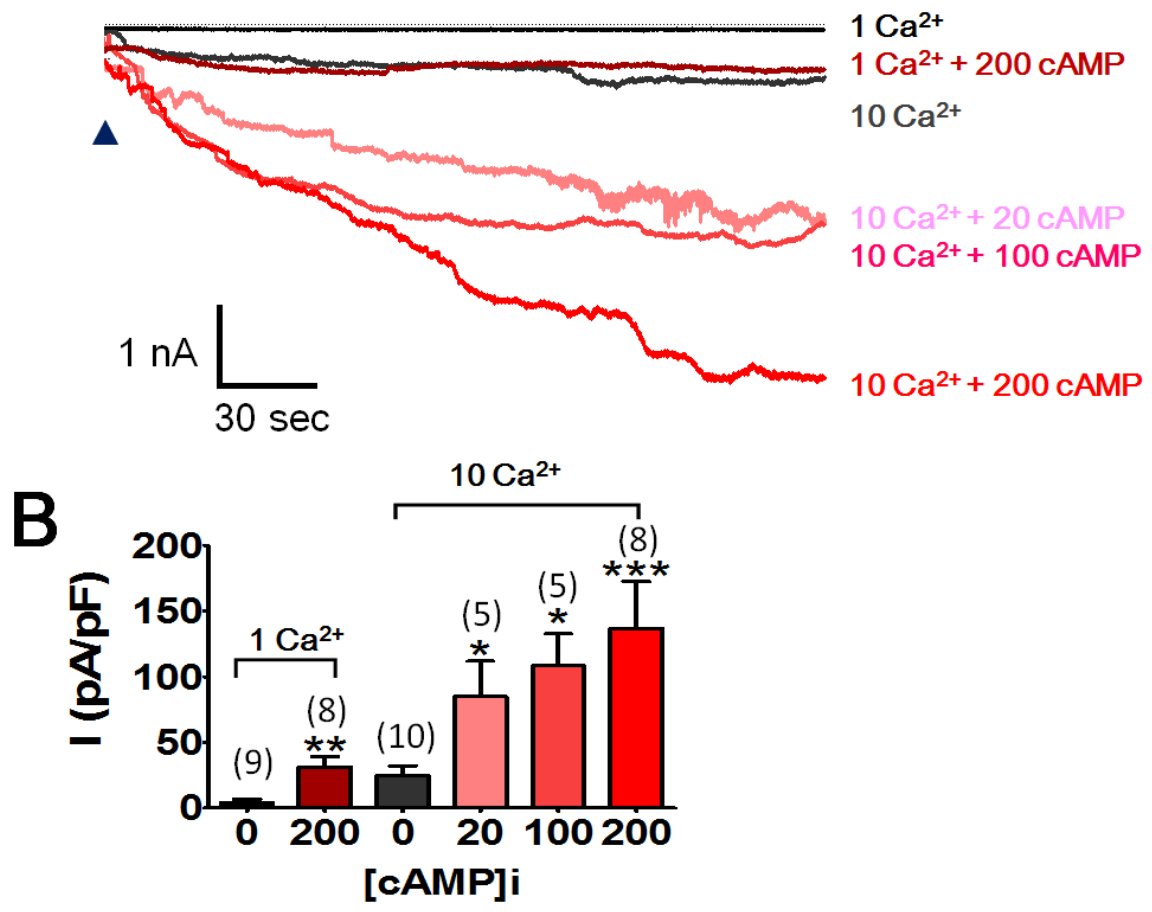

Figure 5. Intracellular calcium augments the cAMP-induced ANO9 activity.

(A) Whole-cell currents ANO9-HEK cells activated by various concentrations of intracellular cAMP or/and $\mathrm{Ca}^{2+}$. The bath and pipette solutions are same as in Fig. 1.

(B) Summary of the cAMP-induced currents at 1 or $10 \mu \mathrm{M} \mathrm{Ca}^{2+} .{ }^{*} \mathrm{p}<0.01,{ }^{* * *} \mathrm{p}<0.001$, one way of ANOVA, Tukey's posthoc test. 
A

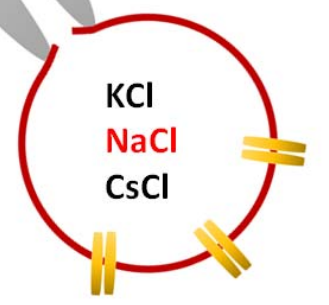

$\mathrm{NaCl} 150$
$\mathrm{KCl} 150$

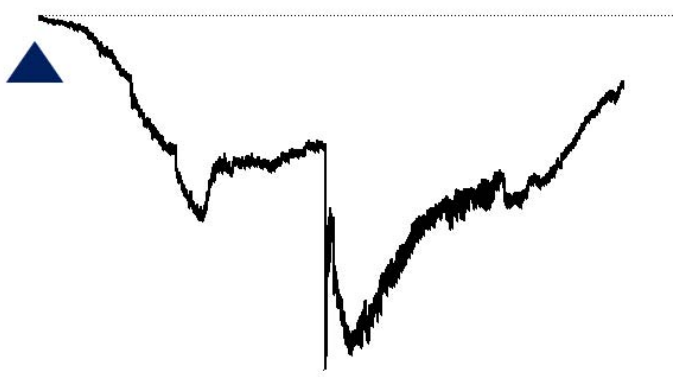

$\mathrm{KCl} 100 / \mathrm{NaCl} 50$

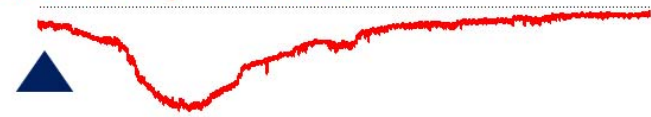

$\mathrm{KCl} 100 / \mathrm{CsCl} 50$

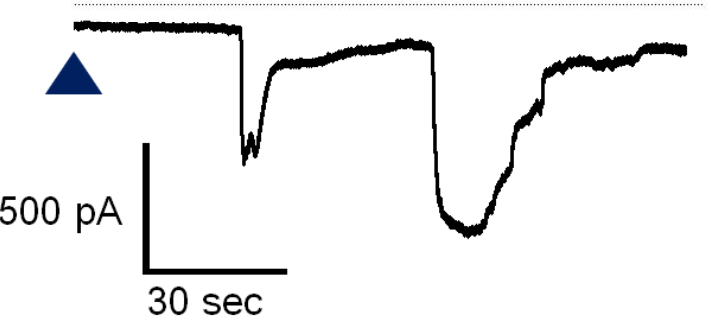

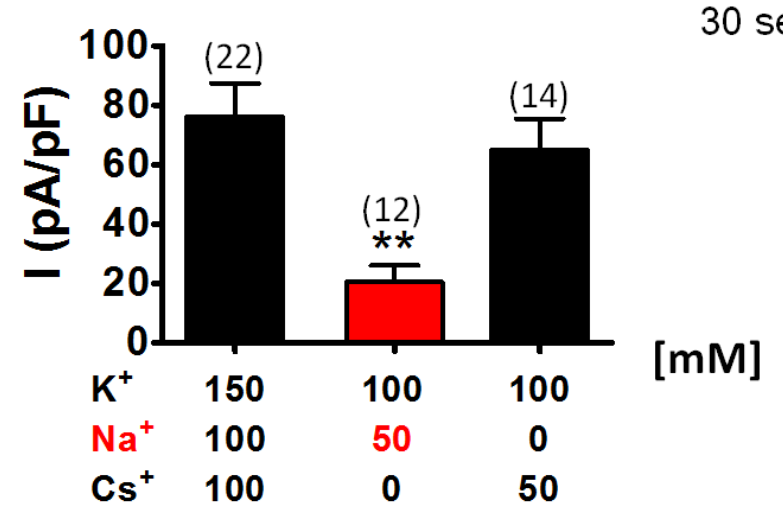

Figure 6. Intracellular sodium inhibits ANO9.

(A) cAMP-induced whole-cell currents of ANO9-HEK cells with or without intracellular $\mathrm{Na}^{+}$. Concentration of $\mathrm{KCl}, \mathrm{NaCl}$ or $\mathrm{CsCl}$ in the pipette solution was shown in each trace. The bath solution contained $140 \mathrm{mM} \mathrm{NaCl}$.

(B) Summary of cAMP-induced currents with different pipette solutions. ${ }^{* *} p<0.01$, one way of ANOVA, Tukey's post-hoc test. 


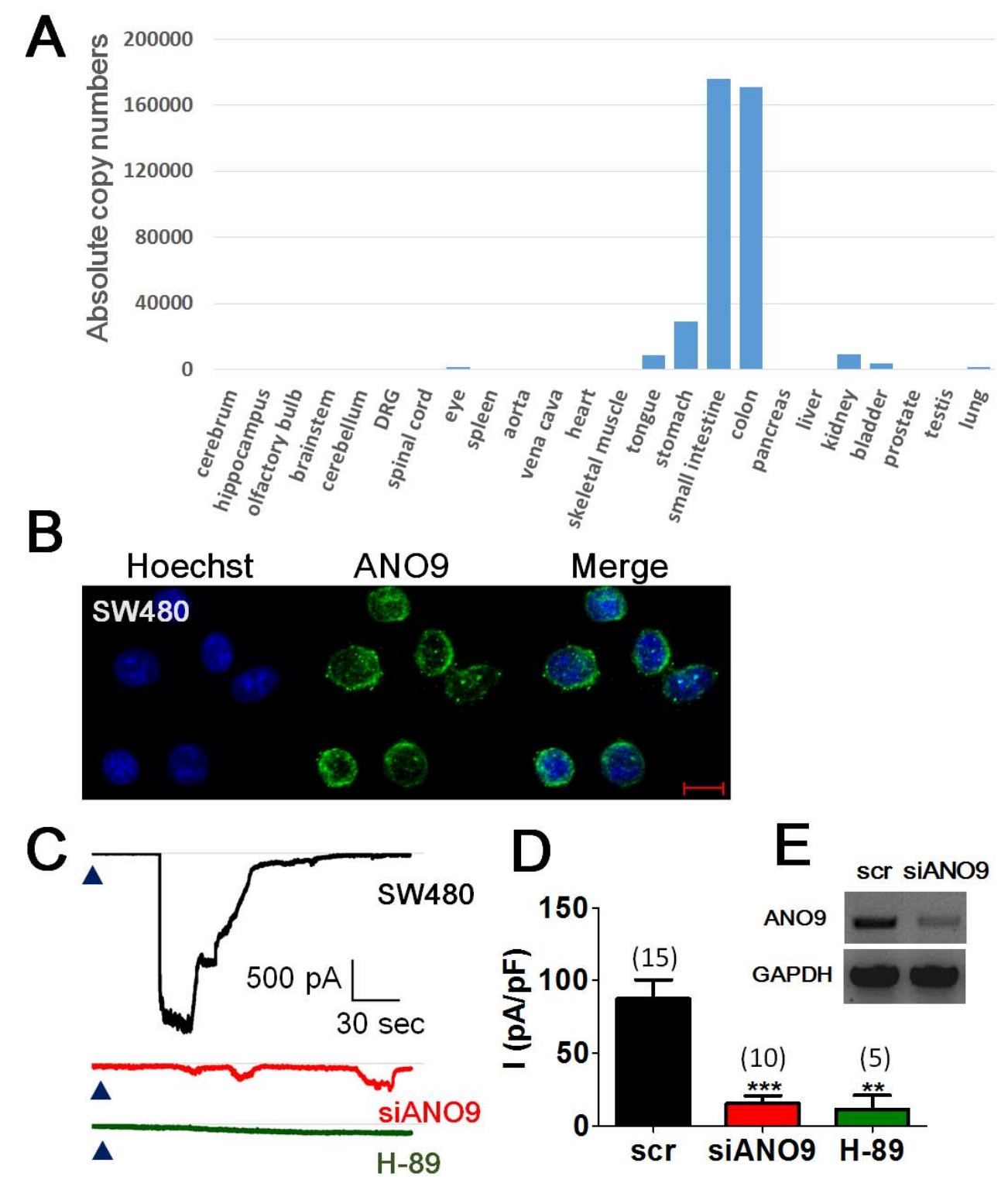

Figure 7. ANO9 is highly expressed in colonic cells.

(A) Real-time quantitative PCR analysis of mRNA transcripts encoding ANO9 in various mouse organs. The levels of transcripts were expressed as absolute copy numbers.

(B) The immunofluorescence of ANO9 in SW480 cells. Scale bar $=10 \mu \mathrm{m}$.

(C) Whole-cell currents activated by intracellular cAMP $(100 \mu \mathrm{M})$ with (upper) or without Ano9 siRNA treatment (middle). The currents were also blocked by the $\mathrm{H}-89$ pretreatment (lower).

(D) Summary of the cAMP-induced currents in the SW480 cells. scr; scrambled siRNA treated, siRNA; Ano9 siRNA treated; $\mathrm{H}-89, \mathrm{H}-89$ treated.

(E) Real-time quantitative PCR products of Ano9 in SW480 cells transfected with scrambled or Ano9 siRNAs. PCR products of glyceraldehyde-3-phosphate dehydrogenase (GAPDH) mRNAs were also shown for control. 


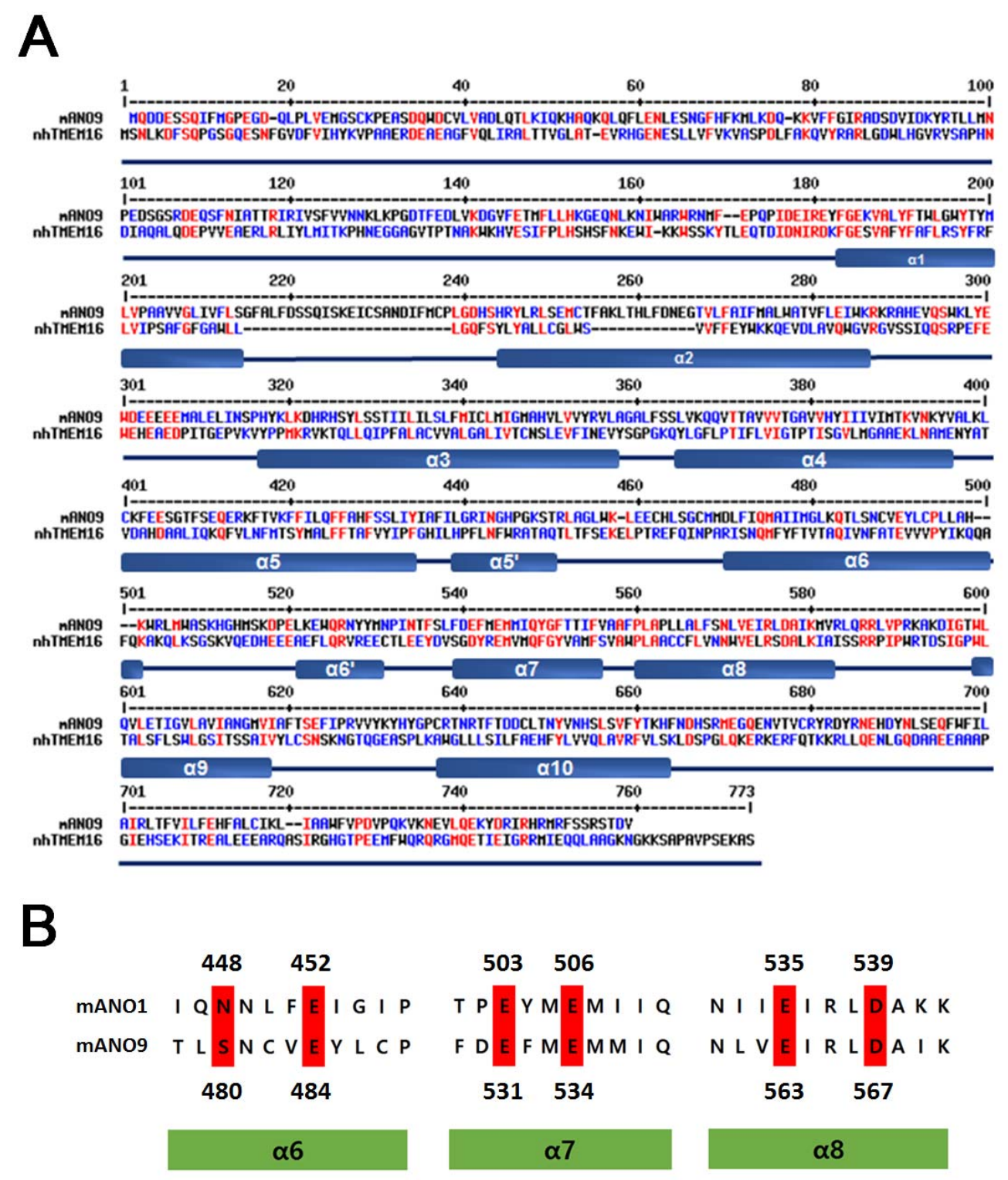

\section{Supplementary Figure 1.}

(A) Structure-based sequence alignment with mouse ANO9 and Nectria haematococca TMEM16 (nhTMEM16). High consensus residues are shown in red. $\alpha$-helices in the crystal structure of nhTMEM16 were also shown in bars.

(B) Sequence alignment with mouse ANO1 and mouse ANO9 at the putative $\mathrm{Ca}^{2+}$ binding sites in ANO1. The conserved amino acids in the putative $\mathrm{Ca}^{2+}$ binding sites are highlighted in red. 
bioRxiv preprint doi: https://doi.org/10.1101/188243; this version posted September 13,2017 . The copyright holder for this preprint (which was not certified by peer review) is the author/funder, who has granted bioRxiv a license to display the preprint in perpetuity. It is made available under aCC-BY 4.0 International license.
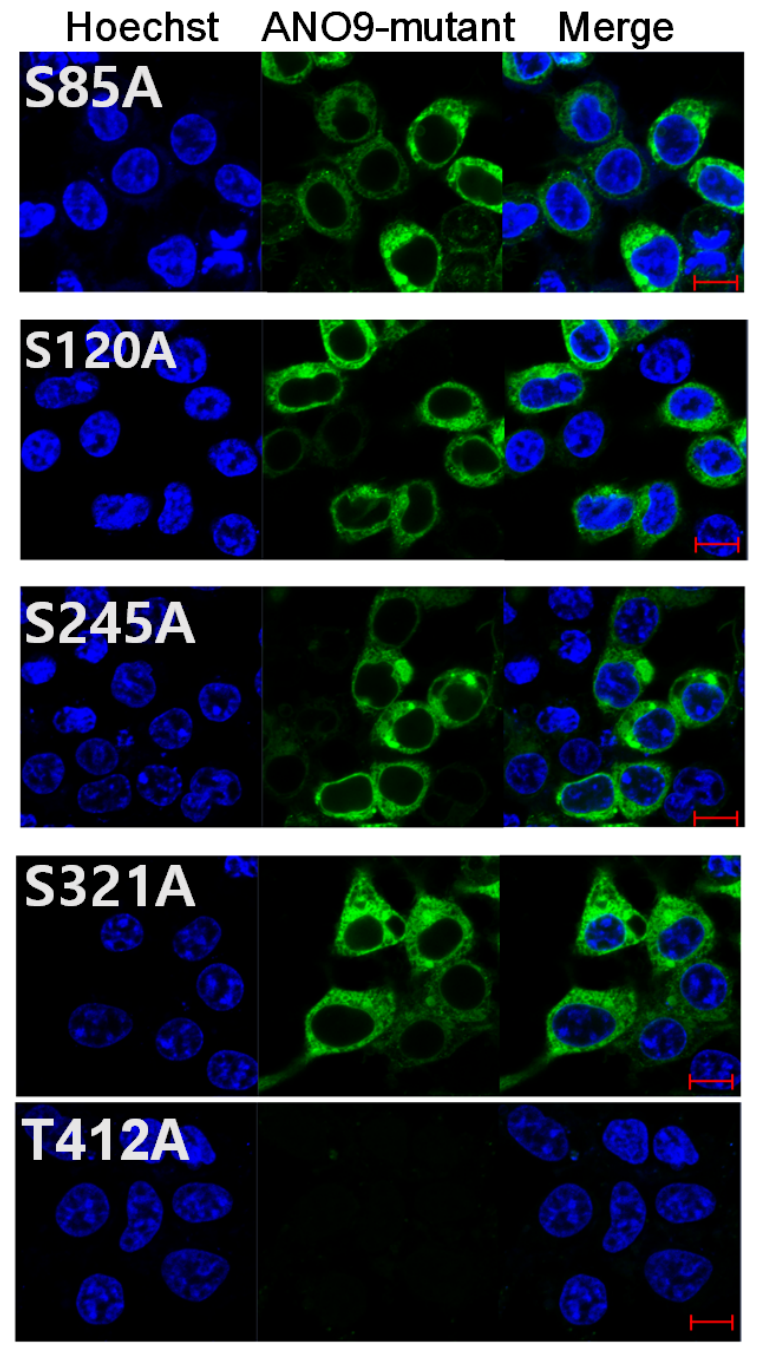

\section{Supplementary Figure 2.}

Overexpression of mANO9 mutants tagged with eGFP such as S85A, S120A, S245A, S321A, or T412A in HEK293T cells. 